\title{
True fractional calcium absorption in Chinese children measured with stable isotopes $\left({ }^{42} \mathrm{Ca}\right.$ and $\left.{ }^{44} \mathrm{Ca}\right)$
}

BY WARREN T. K. LEE ${ }^{1}$, SOPHIE S. F. LEUNG ${ }^{1}$, SUSAN J. FAIRWEATHERTAIT ${ }^{2}$, DORA M. Y. LEUNG ${ }^{1}$, HEIDI S. Y. TSANG ${ }^{1}$, JOHN EAGLES ${ }^{2}$, TOM FOX ${ }^{2}$, S. H. WANG ${ }^{3}$, Y. C. XU ${ }^{3}$, W. P. ZENG ${ }^{4}$, JOSEPH LAU U AND J. R. L. MASAREI ${ }^{5}$

${ }^{1}$ Department of Paediatrics, Faculty of Medicine, The Chinese University of Hongkong, Shatin, Hongkong

${ }^{2}$ AFRC Institute of Food Research, Norwich Laboratory, Norwich Research Park, Colney, Norwich NR4 $7 U A$

${ }^{3}$ Department of Nutrition and Food Hygiene, Sun Yat Sen University of Medical Sciences, Guangzhou, China

${ }^{4}$ Jiangmen Epidemic Station, Jiangmen, Guandong Province, China

${ }^{5}$ Centre for Clinical Trials and Epidemiological Research, Faculty of Medicine, The Chinese University of Hongkong, Shatin, Hongkong

${ }^{6}$ Department of Chemical Pathology, Faculty of Medicine, The Chinese University of Hongkong, Shatin, Hongkong

(Received 13 September 1993 - Revised 12 April 1994 - Accepted 26 April 1994)

\begin{abstract}
True fractional Ca absorption (TFCA) was compared in children with different habitual Ca intakes using a double-label stable-isotope technique. Chinese children aged 7 years from Hongkong $(n 22)$ and Jiangmen ( $n$ 12) participated in the study. An oral administration of $8 \mathrm{mg}{ }^{44} \mathrm{Ca}$ in $100 \mathrm{~g}$ chocolate milk was given shortly after an intravenous injection of $0.75 \mathrm{mg}{ }^{42} \mathrm{Ca}$. Ca isotopic ratios were determined in urine samples collected $24 \mathrm{~h}$ later using thermal-ionization mass spectrometry. There was no significant difference in TFCA between Jiangmen and Hongkong children $(P=0 \cdot 16)$. TFCA of a lower-Ca-intake group $(\mathrm{Ca} \leqslant 500 \mathrm{mg} / \mathrm{d}, n$ 19) with mean $\mathrm{Ca}$ intake $359 \mathrm{mg} / \mathrm{d}$ was 63.1 (SD 10.7) \% and that of a higher-Ca-intake group $(\mathrm{Ca}>500 \mathrm{mg} / \mathrm{d}, n$ 15) with mean $\mathrm{Ca}$ intake $862 \mathrm{mg} / \mathrm{d}$ was 54.8 (SD 7.3)\%; the difference in TFCA was significant $(P=0.016)$. Serum levels of 25 -hydroxycholecalciferol of the children were adequate $(33.7(\mathrm{SD} 7 \cdot 7) \mathrm{ng} / \mathrm{ml})$. The present study indicates that growing children accustomed to a low-Ca diet appear to be able to enhance their absorptive capacity. If it is assumed that dietary $\mathrm{Ca}$ absorption by Chinese children resembles their TFCA from a single meal of chocolate milk, then the recommended dietary allowance (RDA) for Ca for Chinese children would be lower than the US RDA (800 mg/d), which is based on an estimated $40 \% \mathrm{Ca}$ absorption as reported for Caucasian children. A comparative absorption study is necessary to determine whether there is any difference in TFCA between Caucasian and Chinese children.
\end{abstract}

Calcium: Childhood: Double-label stable-isotope technique

In China and Hongkong there has been an increasing concern that children with dietary $\mathrm{Ca}$ intakes below the US recommended dietary allowance (RDA; National Research Council, 1989) would have a lower Ca retention which might result in a reduced peak bone mass (Matkovic et al. 1990; Matkovic, 1991, 1992; Anderson, 1992). Children in China do not usually consume milk and have an average Ca intake of about $300 \mathrm{mg} / \mathrm{d}$ (Ho, 1988; Lee et al. 1993 b). Habitual Ca intakes of 5-year-old children from Jiangmen, Guangdong Province, China, are below $300 \mathrm{mg} / \mathrm{d}$ due to the low consumption of milk and milk products after 1 year of age (Lee et al. 1993b). On the other hand, the eating habits of 
Chinese children in Hongkong are more westernized, and the majority of children continue to consume milk and milk products through at least 5 years of age, resulting in an average Ca intake of about $600 \mathrm{mg} / \mathrm{d}$ (Lee et al. 1993 a). However, there are also some Hongkong children who gradually reduce the amount of milk consumed from age 1 to 5 years so that by 5 years of age their Ca intake is about $300 \mathrm{mg} / \mathrm{d}$ (Lee et al. 1993a,b). There has been no information on $\mathrm{Ca}$ absorption in Chinese children with different levels of $\mathrm{Ca}$ intake, and the capacity of these children to adapt to low $\mathrm{Ca}$ intake by increasing their efficiency of absorption so as to obtain adequate $\mathrm{Ca}$ is not known.

Although the true fractional Ca absorption (TFCA) in humans can be determined using radioisotopes of Ca (DeGrazia et al. 1965; Roth \& Werner, 1985), the inherent potential hazards of ionizing radiation limit its use in infants and children. Recently, with the development of stable inorganic isotope methodology, a safe and accurate method of measuring TFCA in infants and children has been made possible. The use of stable $\mathrm{Ca}$ isotopes in several recent studies has been shown to be an easy and a safe alternative to obtain TFCA data in infants and children under normal and pathological conditions (Yergey et al. 1987; Hillman et al. 1988; Miller et al. 1988).

The present study was designed to examine the hypotheses that children with lower $\mathrm{Ca}$ intakes can compensate by enhancing TFCA, and that there is a negative relationship between habitual $\mathrm{Ca}$ intake and absorption in children. This is the first report of the TFCA of 7-year-old Chinese children on self-selected diets using a double-label stable-isotope technique.

\section{MATERIALS AND METHODS}

\section{Subjects}

Chinese children aged 7 years from Hongkong ( $n$ 22) and from Jiangmen, China ( $n$ 12) took part in the study. The cities of Hongkong and Jiangmen are close, both being located in the geographic region of Guangdong Province in Southern China, and children from both cities are ethnic Cantonese. Hongkong children (twelve boys and ten girls) were randomly selected from a cohort study of growth and nutrition (Leung \& Lui, 1990; Lee et al. $1993 \mathrm{a}$ ). There is a wide range of $\mathrm{Ca}$ intake among Hongkong children depending on whether or not milk is included in the diets. Accurate dietary intake records of these twentytwo Hongkong children had been kept since infancy. Children from Jiangmen in China, on the other hand, seldom consume milk after 1 year of age. Average Ca intake of 5-year-old Jiangmen children was found to be below $300 \mathrm{mg} / \mathrm{d}$ (Lee et al. 1993 b); therefore, the pattern of milk intake among children in Jiangmen is similar to that of children in other regions of Southern China (Ho, 1988). Twelve Jiangmen children (six boys and six girls) from a primary school in Jiangmen were randomly selected for the study. All children fulfilled the selection criteria that they were healthy, growing normally and without any previous major illness or fractures of bones.

\section{Weight and height measurement}

Unclothed weights of children from Hongkong and Jiangmen were measured using a Seca electronic scale (Vogel \& Halke GmbH, Hamburg, Germany) and a beam balance (Model: TGT-100; Lichepai, Guangdong, China) respectively. Standing heights of all children were measured without shoes using a stadiometer (Technical Services Unit, The Chinese University of Hongkong).

\section{Dietary assessment}

Habitual dietary intakes of all children were assessed before the absorption test. Food intake of the Hongkong group was assessed by a research dietitian (W.T.K.L.) using the 
method of dietary history, and cross-checked with a quantitative food-frequency questionnaire and $24 \mathrm{~h}$ recall (Burke, 1947; Marr, 1971; Bingham, 1987; Jain, 1989). Details of the procedures have been described by Lee et al. $(1993 \mathrm{a})$. The dietary assessment method has been a uniform approach to evaluate food intake of the Hongkong cohort since weaning (Leung \& Lui, 1990; Lee et al. 1993a).

Dietary assessment of Jiangmen children was conducted using a quantitative foodfrequency questionnaire (Lee et al. 1993a) which was similar to the one administered in the Hongkong cohort for cross-checking dietary information. The questionnaire was modified for use in the Hongkong Chinese population. The food-frequency questionnaire consisted of food and beverage items commonly consumed by local Chinese. Non-milk foods such as dark-green leafy vegetables, cereals, fish and shell fish, beans and nuts, etc. which had been identified as significant sources of Ca among Chinese children (Lee et al. 1993a) were also listed in the questionnaire in addition to milk and milk products. The foods and beverages in the questionnaire are expressed in common serving size or natural units. Standard household measures like Chinese rice bowls, spoons and Chinese soup spoons, glasses, teacups were used to facilitate portion size description. The parent administered the questionnaire which was subsequently reviewed by a nutritionist. The parent was requested to estimate the frequency in choosing the food items in the questionnaire either per $\mathrm{d}$, per week, or per month.

Nutrient intake was estimated using a computerized food table with food items compiled from appropriate sources (Tung et al. 1961; Department of Health, Education \& Welfare, 1972; Church \& Church, 1975; Paul \& Southgate, 1978; Institute of Health, 1980; Watt \& Merrill, 1983), food manufacturers and food chemists.

\section{Preparation and administration of stable isotopes}

The doses of oral ${ }^{44} \mathrm{Ca}$ and intravenous ${ }^{42} \mathrm{Ca}$ required for administration to children were estimated according to Yergey et al. (1987) $\left(0.2-0.5 \mathrm{mg}{ }^{44} \mathrm{Ca} / \mathrm{kg}\right.$ body weight and $0.02-0.1 \mathrm{mg}{ }^{42} \mathrm{Ca} / \mathrm{kg}$ body weight). Two enriched $\mathrm{Ca}$ isotopes: ${ }^{42} \mathrm{Ca}(83.20$ atom \%) and ${ }^{44} \mathrm{Ca}\left(96.40\right.$ atom \%) in the form of $\mathrm{CaCO}_{3}$ (Technical and Optical Equipment, Tottenham, London) were used as previously described (Fairweather-Tait et al. 1989). The ${ }^{44} \mathrm{Ca}$ solution was prepared by dissolving the $\mathrm{CaCO}_{3}$ in concentrated $\mathrm{HCl}$ (Aristar grade; $2.5 \mathrm{~g} \mathrm{CaCO}_{3}$ in $5 \mathrm{ml} \mathrm{HCl}$ ), adjusting the $\mathrm{pH}$ to 4.0 with $1 \mathrm{M}-\mathrm{NaOH}$ (Aristar grade) and making up the solution with deionized distilled water to a final volume of $316 \mathrm{ml}$. Each dose of approximately $4.3 \mathrm{ml}{ }^{44} \mathrm{Ca}$ was dispensed into a polyethylene tube, sealed and stored at $-20^{\circ}$. The ${ }^{42} \mathrm{Ca}$ solution for injection was prepared in the similar manner but the final $\mathrm{pH}$ was adjusted to 6.0 for intravenous injection. Each $2 \mathrm{ml}$ dose was sealed in a glass ampoule and autoclaved. Samples underwent routine sterility testing in the pharmacy of the Prince of Wales Hospital, Hongkong. The final concentrations of the oral dose of ${ }^{44} \mathrm{Ca}$ solution and intravenous dose of ${ }^{42} \mathrm{Ca}$ solution were 1.83 and $0.359 \mathrm{mg} / \mathrm{ml}$ respectively. The exact quantities of isotopes given to each subject were precisely weighed with an electronic scale accurate to $0.001 \mathrm{mg}$.

Following an overnight fast, ${ }^{42} \mathrm{Ca}$ was administered slowly into the antecubital vein of each subject and then flushed with $5 \mathrm{ml}$ normal saline $(9 \mathrm{~g} \mathrm{NaCl} / \mathrm{l}) \cdot{ }^{44} \mathrm{Ca}$ was mixed in $100 \mathrm{~g}$ chocolate milk when the child was being given the injection. The $\mathrm{Ca}$ concentration of the test meal ( $100 \mathrm{~g}$ chocolate milk) was $120 \mathrm{mg} / 100 \mathrm{~g}$ as determined by atomic absorption spectrometry (Nordin, 1976). The ${ }^{44} \mathrm{Ca}$-enriched chocolate milk was taken by the subject immediately after the injection. The child was not allowed to eat for $2 \mathrm{~h}$ after the test. A standard breakfast consisting of one $75 \mathrm{~g}$ sponge cake and a pack of fruit juice $(250 \mathrm{ml})$ was given $2 \mathrm{~h}$ later. A $500 \mathrm{ml}$ urine sample was collected starting exactly $24 \mathrm{~h}$ after the test to 
determine the ratios of isotopes present in the urine. The urine was collected in an acidwashed bottle until the volume of urine reached the $500 \mathrm{ml}$ mark.

\section{Separation and purification of urine samples}

Microwave digestion. The $500 \mathrm{ml}$ urine sample was placed in an acid-washed beaker and evaporated to approximately $30 \mathrm{ml}$ in volume and then heated slowly to dryness in a polyethylene tube at $80^{\circ}$. The dehydrated urine sample was stored at $-20^{\circ}$ before transporting to Norwich for mass spectrometric analysis. The dehydrated urine sample was reconstituted with $15 \mathrm{ml}$ quartz-distilled water and then digested in concentrated $\mathrm{HNO}_{3}$ ( $1.5 \mathrm{ml}$ urine to $5 \mathrm{ml} \mathrm{HNO}_{3}$, Aristar grade) to release bound $\mathrm{Ca}$ in the organic matrix of urine using a microwave oven (CEM Model MD5-2000 Microwave Sample Preparation System; CEM Corporation, Matthews, NC, USA). Before microwave digestion the mixture of each urine sample and concentrated $\mathrm{HNO}_{3}$ was kept in a digestion vessel overnight (to release gases produced on breaking down of organic constituents). Twelve vessels of urine samples were loaded into the microwave oven at a time. The process of digestion was enhanced by heating the sample in the vessel under controlled pressure. In the initial $30 \mathrm{~min}$ the urine sample was heated at $80-90 \%$ of power to bring up the pressure to $70 \mathrm{lb} / \mathrm{in}^{2}$; then the pressure of the vessel was gradually increased to $85 \mathrm{lb} / \mathrm{in}^{2}$ and maintained at this level under $100 \%$ full power for $1 \mathrm{~h}$.

Anion-exchange columns. Generation of a stable ionic beam from the Ca sample is of paramount importance for an accurate and precise determination of isotopic ratios of $\mathrm{Ca}$ by thermal-ionization mass spectrometry (Mueller \& Walker, 1987; Tackett \& Ellefson, 1987). From a rapid check of the impurities present in the samples using the fast-atombombardment mass spectrometer (FABMS; MS902; Kratos Analytical Instruments, Manchester), we found that the most troublesome impurity interfering with the stability of the $\mathrm{Ca}$ signal was ${ }^{40} \mathrm{~K}$. In order to separate and purify the $\mathrm{Ca}$ from the digested urine two separate sets of anion-exchange-resin columns were used to eliminate inorganic contaminants, especially ${ }^{40} \mathrm{~K}$. The ion-exchange resin used was Dowex $50 \mathrm{~W}$-hydrogen, $8 \%$ cross-linking, 100-200 dry mesh resin (Aldrich Chemical Co., Dorset). The first set of columns was washed with $2 \mathrm{M}-\mathrm{HNO}_{3}$ (Aristar), followed by $0 \cdot 2 \mathrm{M}-\mathrm{HNO}_{3}$. The digested urine samples were evaporated to dryness, redissolved in $0 \cdot 2 \mathrm{M}-\mathrm{HNO}_{3}$ and then applied to the columns which were subsequently washed with $0.2 \mathrm{M}-\mathrm{HNO}_{3}$ before eluting the samples with $2 \mathrm{M}^{-\mathrm{HNO}_{3}}$. The resin in the second set of columns was washed with $5 \cdot 5 \mathrm{M}-\mathrm{HCl}$ (Aristar), followed by quartz-distilled water. The eluates from the previous set of columns were evaporated to dryness, redissolved in $0.04 \mathrm{M}-\mathrm{HCl}$ before loading into the second set of columns. The columns loaded with $\mathrm{Ca}$ samples were flushed with quartz-distilled water; subsequently, the purified $\mathrm{Ca}$ samples were eluted in $1 \mathrm{ml}$ fractions with $1.8 \mathrm{M}-\mathrm{HCl}$. The appearance of maximum concentration of $\mathrm{Ca}$ was found in the 10th-12th fractions as determined by FABMS. Therefore, the $\mathrm{Ca}$ fractions were collected after discarding the first $10 \mathrm{ml}$ of the eluate. The samples were then evaporated to dryness under a $1 \mathrm{~kW}$ lamp in a laminar flow cabinet in the clean room.

Thermal-ionization mass spectrometry (TIMS). The isotopic ratios of the enriched urine samples were determined by TIMS (THQ; Finnegan-Mat GmbH, Bremen, Germany). Each dried sample was dissolved in $50 \mu 10.04 \mathrm{M}-\mathrm{HCl}$. A standard solution $\left(\mathrm{CaCl}_{2}\right)$ was made by replacing the nitrate ions of a Ca standard solution $\left(\mathrm{Ca}\left(\mathrm{NO}_{3}\right)_{2}\right.$; SpectroSol, $\mathrm{BDH}$, Poole, Dorset) with chloride ions using $\mathrm{HCl}$, Aristar grade. Using the double-filament technique (Moore, 1984; Heumann, 1988), $5 \mu \mathrm{l}$ of each sample and a $\mathrm{Ca}$ standard were adsorbed onto a separate evaporation filament by glowing the filament and the sample to dull red before the sample and the standard were loaded into the mass spectrometer. Ca 
masses of $40,41,42$ and 44 of a stable ion beam generated from the sample were sequentially scanned and monitored. The element interferences from ${ }^{40} \mathrm{~K}$ and ${ }^{41} \mathrm{~K}$ were corrected by subtracting the ratios from the pooled isotopic ratios. Each sample was scanned ten times to obtain a mean and a relative standard deviation (one block of data). The final results of ${ }^{40} \mathrm{Ca}:{ }^{44} \mathrm{Ca}$ and ${ }^{40} \mathrm{Ca}:{ }^{42} \mathrm{Ca}$ were obtained by determining the mean of five blocks of data (fifty scans). The relative standard deviation (RSD) of Ca ratio determination in the present study was $0 \cdot 1-0 \cdot 3 \%$.

Calculation of TFCA. The calculation of TFCA (\%) was based on the assumption that both intravenously and orally administered $\mathrm{Ca}$ isotopes were metabolized at the same rate once the state of equilibrium was achieved. The percentage absorption from the oral dose was determined according to the following equation (Yergey et al. 1987):

$$
\text { TFCA } \%=\frac{\left(\mathrm{na}^{44} \mathrm{Ca}\right)\left({ }^{42} \mathrm{Ca} \text { i.v. }\right) \times \Delta \% \mathrm{XS}^{44} \mathrm{Ca} \times 100}{\left(\mathrm{na}^{42} \mathrm{Ca}\right)\left({ }^{44} \mathrm{Ca} \text { oral }\right) \times \Delta \% \mathrm{XS}^{42} \mathrm{Ca}},
$$

where na is the natural abundance of the two isotopes, i.v. and oral are the exact dose administered, and $\Delta \% \mathrm{XS}$ is the degree to which a particular ratio differs from the natural ratios.

\section{Measurement of serum concentration of 25-hydroxycholecalciferol (25-OHD)}

Serum concentration of 25-OHD was measured using a competitive protein assay as described previously (Woo et al. 1990; Chan et al. 1992) in the Hongkong study children before the absorption study (during the autumn month of October). Twenty children agreed to have blood taken. Venous blood $(2 \mathrm{ml})$ was drawn and serum was separated and stored at $-70^{\circ}$ until analysis. 25-OHD was extracted with acetonitrile and separated using a SepPak C-18 cartridge (Waters Associated, Milford, MA, USA). The extract was then analysed by competitive-protein-binding assay using a commercial kit (Amersham International, Amersham, Bucks.).

\section{Statistical methods}

The non-parametric Mann-Whitney $U$ test was used to compare group mean differences between various Ca-intake groups owing to the small sample size and some observed skewness in the data. The non-parametric Kruskal-Wallis test was used to test the overall mean differences in baseline dietary intake and body size among three groups of children with different $\mathrm{Ca}$ intakes. Two-sided significance level was set at $\boldsymbol{P}<0.05$ for test statistics. Statistical analysis was performed by SPSS/PC, Version 4.0, SPSS Inc., Chicago, IL, USA. The power of the statistics was tested by Power, Version 1.3, 1985 (Lavel University, Ste. Foy, Quebec, Canada).

\section{Ethical considerations}

The study protocol was approved by the Ethics Committees of The Faculty of Medicine, The Chinese University of Hongkong and the AFRC Institute of Food Research. Informed consent was obtained from all the parents.

\section{RESULTS}

Table 1 shows the comparisons of dietary intake and body size of Hongkong and Jiangmen children at 7 years of age. The mean $\mathrm{Ca}$ intake of Hongkong children was 693 (SD 410$) \mathrm{mg} / \mathrm{d}$ with a wide range of variation $(185-1641 \mathrm{mg} / \mathrm{d})$ because the subjects included children who consumed milk regularly $(n 14)$ and those who did not drink milk 
Table 1. Mean dietary intakes and body size of 7-year-old Hongkong and Jiangmen children*

(Mean values and standard deviations)

\begin{tabular}{|c|c|c|c|c|c|c|c|}
\hline \multirow[t]{2}{*}{ Study group... } & \multicolumn{3}{|c|}{ Hongkong (n 22) } & \multicolumn{3}{|c|}{ Jiangmen $(n 12)$} & \multirow{2}{*}{$\begin{array}{c}\text { Statistical significance } \\
\text { of difference between } \\
\text { means } \dagger: P=\end{array}$} \\
\hline & Mean & SD & Range & Mean & SD & Range & \\
\hline $\mathrm{Ca}(\mathrm{mg} / \mathrm{d})$ & 693 & 410 & $185-1641$ & 381 & 103 & $172-552$ & 0.0062 \\
\hline $\mathrm{Ca}$ :energy (mg/MJ) & $85 \cdot 3$ & $34 \cdot 2$ & & $81 \cdot 3$ & $14 \cdot 3$ & $53-103$ & 0.83 \\
\hline $\mathrm{P}(\mathrm{mg} / \mathrm{d})$ & 1002 & 327 & $545-1803$ & 683 & 180 & $436-1062$ & 0.0017 \\
\hline $\mathrm{Ca}: \mathrm{P}$ & 0.66 & 0.22 & $0.30-1.2$ & $0 \cdot 56$ & 0.12 & $0.39-0.79$ & $0 \cdot 17$ \\
\hline Energy $(\mathrm{KJ} / \mathrm{d})$ & 7724 & 1874 & $5644-12949$ & 4678 & 1021 & $3226-6899$ & $<0.0001$ \\
\hline Protein $(\mathrm{g} / \mathrm{d})$ & 77 & 19 & $49-117$ & 58 & 17 & $38-88$ & 0.0049 \\
\hline Wt (kg) & $20 \cdot 9$ & 2.57 & $17 \cdot 2-27 \cdot 4$ & $21 \cdot 3$ & 3.2 & $17.8-27.9$ & 0.75 \\
\hline Height (m) & $1 \cdot 19$ & 0.04 & $1.15-1.29$ & $1 \cdot 20$ & 0.04 & $1.14-1.26$ & 0.87 \\
\hline
\end{tabular}

* For details of subjects, see p. 884 and pp. 887-888.

$\dagger$ Mann-Whitney U test.

( $n$ 8). In contrast, the mean $\mathrm{Ca}$ intake of Jiangmen children was 381 (SD 103) $\mathrm{mg} / \mathrm{d}$ with a narrow range of $172-552 \mathrm{mg} / \mathrm{d}$. There was only one girl with $\mathrm{Ca}$ intake slightly above $500 \mathrm{mg} / \mathrm{d}(525 \mathrm{mg} / \mathrm{d})$. Food habits of the Jiangmen group were characterized by low intake of milk and milk products, and dark-green leafy vegetables were the principal source of dietary $\mathrm{Ca}$. In fact, the low-milk-drinking Hongkong children had low $\mathrm{Ca}$ intake (359 (SD 94) $\mathrm{mg} / \mathrm{d}$ ) comparable with their counterparts in Jiangmen (366 (SD 92) $\mathrm{mg} / \mathrm{d} ; \boldsymbol{P}=$ 0.93). Children from Hongkong consumed more animal products and snack foods than Jiangmen children, e.g. chicken wings, burgers and sugary drinks, etc. Dietary intakes of energy $(P<0.0001), \mathrm{P}(P=0.0017)$ and protein $(P=0.00049)$ in Hongkong children were, therefore, significantly higher than those of Jiangmen children. Although the Ca intake of Hongkong children was higher than that of Jiangmen children $(P=0.0062)$, Ca intake corrected for energy intake (Ca:energy; $\mathrm{mg} / \mathrm{MJ}$ ) was not different between the two groups $(P=0.83)$. There were no significant differences in weight $(P=0.75)$ and height $(P=0.87)$ between the Hongkong group and Jiangmen group (Table 1).

\section{TFCA and Ca intake of children at 7 years old}

TFCA values of twelve Jiangmen children and twenty-two Hongkong children were 63.1 (SD 11.4) and 57.4 (SD 9.1)\% respectively. However, the mean difference in TFCA between Jiangmen and Hongkong children was not statistically significant $(P=0 \cdot 16)$. If the observed mean and SD for TFCA of the Jiangmen group and Hongkong group reflect the population means, the observed statistical power was only 0.45 (with type I error rate $(\alpha)$ 0.05 , two-sided). Therefore, it is possible that the mean TFCA of Jiangmen children may be significantly higher than that of Hongkong children if the sample size increases.

All the study children from both Hongkong and Jiangmen were ethnic Cantonese from Southern China and they were of the same age. Although the two dietary assessment methods were slightly different, a similar quantitative food-frequency questionnaire with a list of milk and non-milk food items identified as the substantial sources of Ca among Chinese children was used to estimate $\mathrm{Ca}$ intake among all the study children. Both dietary assessment methods together revealed that the levels of $\mathrm{Ca}$ intake for low-milk-drinking Jiangmen and Hongkong children were not significantly different $(P=0.93)$. Thus, the slight difference in the dietary assessment methodology did not appear to affect the 
Table 2. Classification of 7-year-old Hongkong and Jiangmen children into groups $A-E$ according to country of origin and calcium intake* $\dagger$

\begin{tabular}{lrlc}
\hline $\begin{array}{l}\text { Classification } \\
\text { group }\end{array}$ & $n$ & \multicolumn{1}{c}{ Location(s) } & Ca intake (mg/d) \\
\hline A & 19 & Hongkong+ Jiangmen & $\leqslant 500$ \\
B & 15 & Hongkong+ Jiangmen & $>500$ \\
C & 8 & Hongkong & $\leqslant 500$ \\
D & 11 & Jiangmen & $\leqslant 500$ \\
E & 14 & Hongkong & $>500$ \\
\hline \hline
\end{tabular}

* For details of subjects, see p. 884, pp. 887-888 and Table 1.

$\dagger$ One child from Jiangmen with Ca intake at $550 \mathrm{mg} / \mathrm{d}(>500 \mathrm{mg} / \mathrm{d}$ ) was excluded from the classification due to inadequate sample size.

Table 3. Mean dietary intake, body size and true fractional calcium absorption (TFCA) of 7year-old Hongkong and Jiangmen children classified according to calcium intake into groups $A(\mathrm{Ca} \leqslant 500 \mathrm{mg} / \mathrm{d})$ and $B(\mathrm{Ca}>500 \mathrm{mg} / \mathrm{d})^{*}$

(Mean values and standard deviations)

\begin{tabular}{|c|c|c|c|c|c|c|c|}
\hline \multirow[t]{2}{*}{ Study group... } & \multicolumn{3}{|c|}{$\mathrm{A}(n 19)$} & \multicolumn{3}{|c|}{$\mathbf{B}(n 15)$} & \multirow{2}{*}{$\begin{array}{c}\text { Statistical significance } \\
\text { of difference between } \\
\text { means } \dagger: P=\end{array}$} \\
\hline & Mean & $\mathrm{SD}$ & Range & Mean & SD & Range & \\
\hline $\mathrm{Ca}(\mathrm{mg} / \mathrm{d})$ & 363 & 91 & $172-500$ & 862 & 394 & $505-1641$ & $<0.0001$ \\
\hline Energy $(\mathrm{KJ} / \mathrm{d})$ & 5355 & 1324 & $3226-8134$ & 8290 & 1957 & $5751-12949$ & 0.0001 \\
\hline Ca:energy (mg/MJ) & $70 \cdot 4$ & $20 \cdot 1$ & $31 \cdot 8-103 \cdot 3$ & $101 \cdot 1$ & 28.9 & $70 \cdot 5-164 \cdot 1$ & $0 \cdot 0047$ \\
\hline$P(\mathrm{mg} / \mathrm{d})$ & 716 & 163 & $436-1041$ & 1109 & 340 & $724-1803$ & $0 \cdot 0001$ \\
\hline $\mathrm{Ca}: \mathrm{P}$ & $0 \cdot 52$ & $0 \cdot 13$ & $0.3-0.79$ & 0.76 & $0 \cdot 17$ & $0 \cdot 5-1 \cdot 2$ & 0.0001 \\
\hline Protein (g/d) & $61 \cdot 6$ & $18 \cdot 3$ & $37 \cdot 9-114.7$ & $81 \cdot 6$ & $17 \cdot 6$ & $56 \cdot 3-117 \cdot 1$ & 0.0024 \\
\hline Wt $(\mathrm{kg})$ & $19 \cdot 8$ & $2 \cdot 3$ & $17 \cdot 2-24 \cdot 3$ & $21 \cdot 5$ & $2 \cdot 6$ & $17 \cdot 7-27 \cdot 9$ & $0 \cdot 13$ \\
\hline Height (m) & $1 \cdot 20$ & 0.04 & $1 \cdot 14-1 \cdot 26$ & $1 \cdot 19$ & 0.04 & $1 \cdot 15-1 \cdot 30$ & 0.92 \\
\hline TFCA $(\%)$ & $63 \cdot 1$ & $10 \cdot 7$ & $48 \cdot 1-84 \cdot 6$ & $54 \cdot 8$ & $7 \cdot 3$ & $46 \cdot 0-68 \cdot 2$ & $0 \cdot 016$ \\
\hline
\end{tabular}

* For details of subjects, see p. 884 and Table 1.

$\dagger$ Mann-Whitney U test.

estimation of $\mathrm{Ca}$ intake to a great extent. As a result, the study children from both Hongkong and Jiangmen may be grouped together in order to compare their TFCA with respect to their habitual $\mathrm{Ca}$ intakes. $\mathrm{Ca}$ intake at $500 \mathrm{mg} / \mathrm{d}$ recommended by Food and Agriculture Organization/World Health Organization Expert Group (1962) was used as a cut-off point to allocate children into group $\mathrm{A}$ or $\mathrm{B}$. Table 2 shows the grouping of children according to the country of origin and the level of Ca intake. Group A consisted of nineteen children (nine boys and ten girls) with a habitual Ca intake $\leqslant 500 \mathrm{mg} / \mathrm{d}$, whereas group $\mathrm{B}$ consisted of fifteen children (nine boys, six girls) with a habitual Ca intake $>500 \mathrm{mg} / \mathrm{d}$. Mean dietary intake, body size and TFCA of groups A and B are given in Table 3. Nutrient intakes of regular-milk-drinking children (group B) were significantly higher than those of the low-milk-drinking children (group A; Table 3). The differences in nutrient intakes between groups $\mathrm{A}$ and $\mathrm{B}$ may be due to the fact that a majority of the children in group $\mathrm{B}$, comprising Hongkong children, consumed more foods rich in energy, protein and $\mathrm{P}$. In addition, a higher consumption of milk in group B might also contribute to the difference in dietary intake. Fig. 1 shows the distribution of TFCA for the study children in groups 


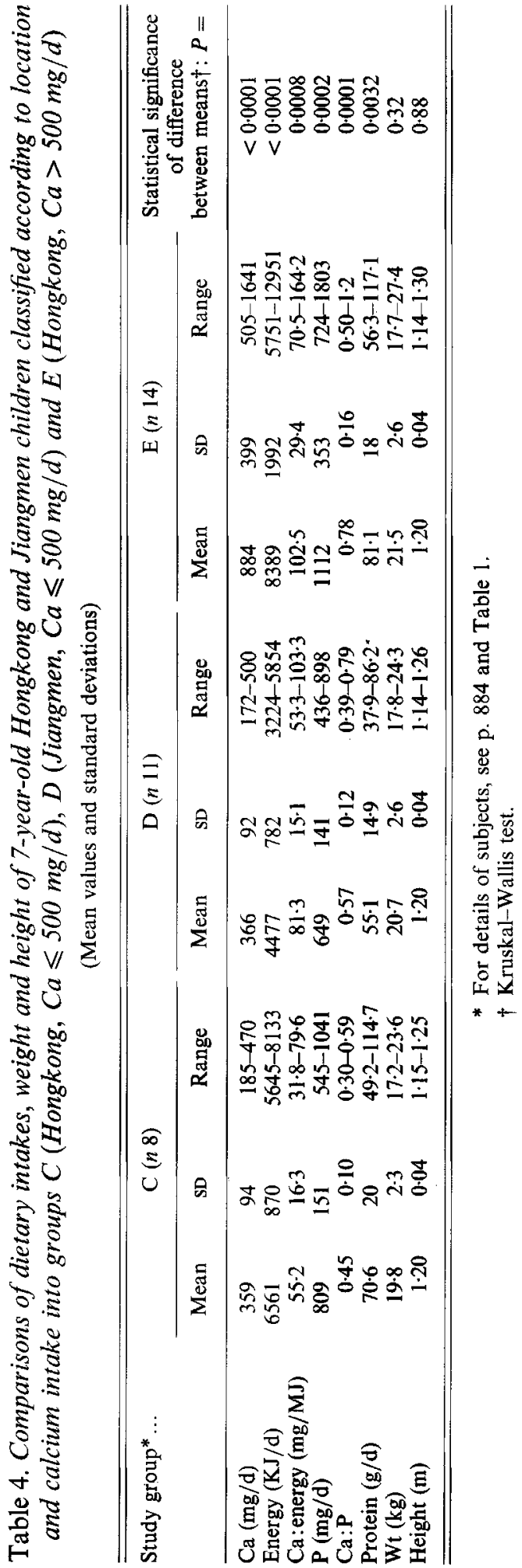


Table 5. Comparisons of mean true fractional calcium absorption (TFCA) of 7-year-old Hongkong and Jiangmen children classified according to location and $\mathrm{Ca}$ intake into groups $C$ (Hongkong, Ca $\leqslant 500 \mathrm{mg} / \mathrm{d}$ ), D (Jiangman, Ca $\leqslant 500 \mathrm{mg} / \mathrm{d}$ ) and $E$ (Hongkong, $\mathrm{Ca}>500 \mathrm{mg} / \mathrm{d})$

(Mean values and standard deviations)

\begin{tabular}{|c|c|c|c|c|c|c|}
\hline \multirow[b]{2}{*}{ Study group ${ }^{* \dagger}$} & \multirow[b]{2}{*}{$n$} & \multicolumn{3}{|c|}{ TFCA $(\%)$} & \multicolumn{2}{|c|}{$\mathrm{Ca}$ intake $(\mathrm{mg} / \mathrm{d})$} \\
\hline & & Mean & SD & Range & Mean & SD \\
\hline $\mathrm{C}$ & 8 & $62 \cdot 1$ & $9 \cdot 95$ & $55 \cdot 1-84 \cdot 6$ & 359 & 94 \\
\hline D & $11 \pm$ & $63 \cdot 7$ & $11 \cdot 7$ & $48 \cdot 1-82 \cdot 7$ & 366 & 92 \\
\hline E & $14^{4}$ & $54 \cdot 7$ & $7 \cdot 6$ & $46 \cdot 0-68 \cdot 2$ & 884 & 399 \\
\hline
\end{tabular}

* For details of subjects, see p. 884 and Table 1.

$\uparrow$ Mean values for TFCA were compared by Mann-Whitney $U$ test: group $\mathrm{C} v$. group $\mathrm{E}, \boldsymbol{P}=0.076$; group D $v$. group $\mathrm{E}, P=0.033$; group $\mathrm{C} v$. group $\mathrm{D}, P=0.93$.

$\ddagger$ One Jiangmen child with a Ca intake of $550 \mathrm{mg} / \mathrm{d}$ was not included in the analysis.

A and B. The mean TFCA for group A with a Ca intake $\leqslant 500 \mathrm{mg} / \mathrm{d}$ was $63 \cdot 1$ (sD 10.7) $\%$ which was significantly higher than that of group B with a Ca intake $>500 \mathrm{mg} / \mathrm{d}(54.8$ (SD 7.3) $\% ; P=0.016$; Table 3).

All the study children from the two groups (A and B) were further re-allocated to groups $\mathrm{C}-\mathrm{E}$ with respect to their place of origin and the level of $\mathrm{Ca}$ intake (Table 2). Eight Hongkong children with $\mathrm{Ca}$ intake $\leqslant 500 \mathrm{mg} / \mathrm{d}$ were re-allocated into group C. Eleven Jiangmen children with $\mathrm{Ca}$ intake $\leqslant 500 \mathrm{mg} / \mathrm{d}$ were re-allocated into group D. Fourteen Hongkong children with Ca intake $>500 \mathrm{mg} / \mathrm{d}$ were re-allocated into group E. One child from Jiangmen with $\mathrm{Ca}$ intake $>500 \mathrm{mg} / \mathrm{d}$ was excluded from the analysis because of an inadequate sample size. The mean Ca intakes of groups C, D and E were 359 (SD 94), 366 (SD 92) and 884 (SD 399) $\mathrm{mg} / \mathrm{d}$ respectively. The overall differences in dietary intake, weight and height of children in groups C, D and E were tested by the Kruskal-Wallis test (Table 4). There were significant differences between the three groups in nutrient intakes but not in body weight $(P=0.32)$ and height $(P=0.88)$ (see Table 4). Table 5 compares the differences in TFCA between groups C, D and E by using the Mann-Whitney U test. TFCA values of groups $\mathrm{C}$ and $\mathrm{E}$ were 62.1 (SD 9.95) and 54.7 (SD 7.6) \% respectively; there was no significant difference in TFCA between groups $\mathrm{C}$ and $\mathrm{E}(P=0.076)$. If the observed means and standard deviations for TFCA for groups $\mathrm{C}$ and $\mathrm{E}$ reflect the population means, the observed statistical power was only 0.5 (with type I error rate $(\alpha) 0.05$, two-sided). Therefore, it is possible that the mean TFCA for group D may be significantly higher than that for group $\mathrm{E}$ if the number of subjects increases. The TFCA for group D (63.73 (SD 11.7$) \%$ ) was significantly higher than that for group E (54.7 (SD 7.6) $\% ; P=0.033$ ). There was no significant difference in TFCA and mean $\mathrm{Ca}$ intake between groups $\mathrm{C}$ and $\mathrm{D}(P=0.93$ for both groups), which supports the previous attempt to combine ethnically similar study children with the same age and comparable low $\mathrm{Ca}$ intakes for TFCA comparison.

Although TFCA in the low-Ca-intake children was found to be significantly higher than that for the high-Ca-intake children, there was no significant negative association between TFCA and Ca intake $(r-0 \cdot 28, P=0 \cdot 11, n 34)$. The non-significant association might be explained by the fact that Ca intake may not be linearly related to TFCA (Heaney et al. 1975; Eastell et al. 1989), or it may be due to a small sample size. On the other hand, there was a borderline significant negative relationship between TFCA and current protein 


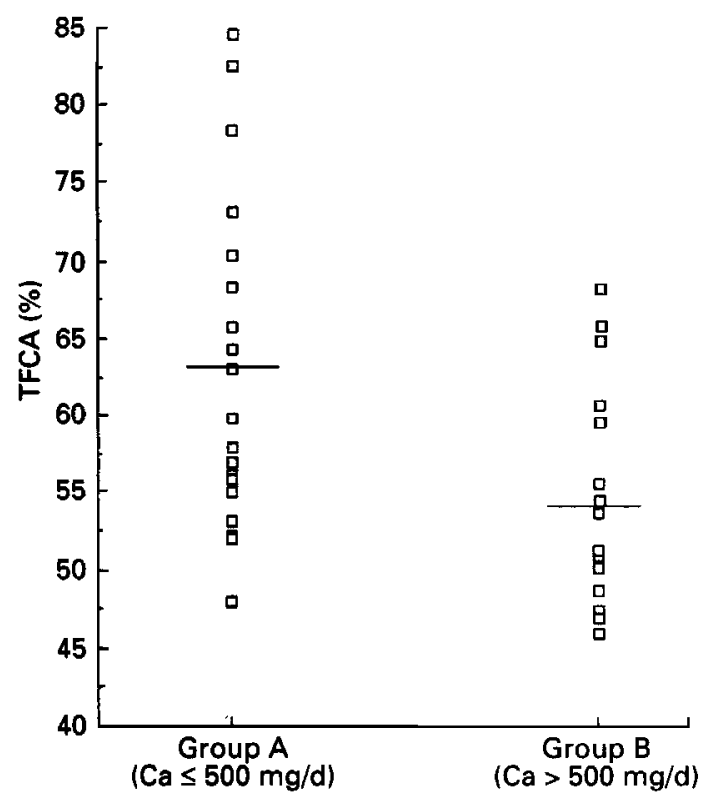

Fig. 1. Distribution of true fractional calcium absorption (TFCA) and Ca intakes of thirty-four 7-year-old Hongkong and Jiangmen children classified according to $\mathrm{Ca}$ intake into groups $\mathrm{A}(\mathrm{Ca} \leqslant 500 \mathrm{mg} / \mathrm{d})$ and $\mathrm{B}$ $(\mathrm{Ca}>500 \mathrm{mg} / \mathrm{d})$. For details of subjects, see p. 884. $\_$, Mean value.

intake $(r-0 \cdot 33, P=0.056)$ which might be due to the fact that protein intake was highly correlated with $\mathrm{Ca}$ intake in these children $(r 0.68, P<0.0001)$. Otherwise, TFCA was not related to any dietary variables of carbohydrate $(P=0.35)$, fat $(P=0.29), \mathrm{P}(P=0.067)$, body weight $(P=0.65)$ and height $(P=0.99)$. In addition, there was a large inter-subject variation in $\mathrm{Ca}$ absorption in both the low- and high-Ca-intake groups (Fig. 1).

\section{Serum level of 25-OHD in twenty Hongkong study children}

The mean serum 25-OHD level in twenty Hongkong study children was $33 \cdot 7$ (SD $7 \cdot 7$, range 19-0-48.4) $\mathrm{ng} / \mathrm{ml}$. The serum 25-OHD levels of children with $\mathrm{Ca}$ intakes less than and greater than $500 \mathrm{mg} / \mathrm{d}$ were $32 \cdot 9$ (SD 7.0, $n$ 7) and $34 \cdot 1$ (SD 7.9, $n$ 13) $\mathrm{ng} / \mathrm{ml}$ respectively. There was no significant difference in serum 25-OHD level between the lower- and higherCa-intake groups $(P=0.66)$. There was also no correlation between the serum 25-OHD level and baseline TFCA $(r-0 \cdot 29, P=0 \cdot 21)$. Using serum $25-\mathrm{OHD}$ level at $10 \mathrm{ng} / \mathrm{ml}$ as a diagnostic index of vitamin D deficiency (Grindulis et al. 1986), the vitamin D nutritional status of the Hongkong study children was within the normal range.

\section{DISCUSSION}

Ca moves across the intestine in both directions; the $\mathrm{Ca}$ absorbed from the gut could be secreted as endogenous $\mathrm{Ca}$ into the gut lumen and subsequently reabsorbed from it. Net fractional $\mathrm{Ca}$ absorption determined by traditional balance studies fails to differentiate the endogenous $\mathrm{Ca}$ from the dietary source. However, the technique of doubly labelled isotopes measures TFCA by giving one isotope orally and the other one intravenously which can correct for the endogenous $\mathrm{Ca}$ secreted into the intestine. The determination of TFCA using double-label isotopes only requires a sample of body fluids, e.g. urine and blood, collected $24 \mathrm{~h}$ after dosing. The measurement does not depend on the absolute quantities of the two labelled isotopes but the ratio of the two isotopes in the body fluids. 
Thus, the technique is not subject to inherent errors incurring in a metabolic balance study. Furthermore, the use of stable isotopes to determine fractional $\mathrm{Ca}$ absorption was found to be highly correlated with the technique of radioisotopes (Yergey et al. 1987; Eastell et al. 1989). The test is less time consuming, taking a few minutes to administer the tracers, whereas a balance study needs several weeks to complete. TIMS is a more accurate and sensitive technique than the FABMS for measuring inorganic isotopes (Fairweather-Tait et al. 1989). It has a precision of $0.3-0.5 \%$; therefore, lower doses can be used, so that the cost of isotopes can be reduced. Furthermore, for studies in infants and children who have a smaller exchangeable Ca pool, doses can be further scaled down (Eastell et al. 1989). In the present study chocolate milk was used instead of ordinary milk as a carrier for ${ }^{44} \mathrm{Ca}$ isotope. Some nutrition textbooks state that $\mathrm{Ca}$ in chocolate milk is less readily available for absorption than unflavoured cow's milk due to the presence of oxalate in chocolate. However, Recker et al. (1988), using radioisotopes to compare fractional absorption of $\mathrm{Ca}$ from chocolate milk, whole milk, yoghurt, cheese and $\mathrm{CaCO}_{3}$ in healthy subjects, found that there were no significant differences in the relative absorbability between chocolate milk and any of these tested dairy products as well as $\mathrm{CaCO}_{3}$ suggesting that the absorbability of $\mathrm{Ca}$ from chocolate milk is comparable with that of unflavoured cow's milk. There is a limitation in the present study: the use of chocolate milk as a single carrier for the ${ }^{44} \mathrm{Ca}$ might give a result representing how well the $\mathrm{Ca}$ from chocolate milk is absorbed but may not be representative of the $\mathrm{Ca}$ absorption from the whole diet. Despite this factor, the absorption test was standardized throughout the present study, and it was still possible to use chocolate milk as a single $\mathrm{Ca}$ carrier in order to differentiate between higher absorbers with low $\mathrm{Ca}$ intake and lower absorbers with high $\mathrm{Ca}$ intake.

The present study shows that the study children with a mean $\mathrm{Ca}$ intake of about $360 \mathrm{mg} / \mathrm{d}$ had a significantly higher TFCA $(63 \%)$ than that of children with mean Ca intake $860 \mathrm{mg} / \mathrm{d}(55 \%)$. The results indicate that the study children with low $\mathrm{Ca}$ intakes were able to adapt to the habitual diets with $\mathrm{Ca}$ intake below the RDA suggested for most developed countries (National Research Council, 1989; Department of Health, 1991; German Society of Nutrition, 1991). Physiologically, it is vitally important that the growing Chinese children accustomed to a non-milk diet were able to enhance the efficiency of the $\mathrm{Ca}$ absorptive mechanism in order to compensate for the low $\mathrm{Ca}$ intake.

The success of physiological adaptation depends on the systemic mediation of parathyroid hormone and vitamin $\mathrm{D}$ in response to a low habitual Ca diet (Hegsted et al. 1952; Norman, 1990). During growth the active process of bone remodelling leads to an increased demand for $\mathrm{Ca}$ in skeletal development, the increased production of parathyroid hormone and 1,25-dihydroxycholecalciferol may ultimately stimulate the synthesis of Cabinding protein, intestinal $\mathrm{Ca}$ absorption would be enhanced to compensate for the low$\mathrm{Ca}$ diet, and urinary $\mathrm{Ca}$ excretion may be reduced as well (Norman, 1990). In this way the body may adapt to achieve a positive $\mathrm{Ca}$ balance for maintaining $\mathrm{Ca}$ homeostasis appropriate for skeletal mineralization. Classical $\mathrm{Ca}$ balance studies in low-Ca-intake children, adolescents and adults have together demonstrated that urinary excretion is reduced (Hegsted et al. 1952; Begum \& Pereira, 1969; Matkovic, 1991). In the current study the serum 25-OHD level of the Hongkong children was within the normal range. In fact, serum concentrations of 25-OHD have been determined in eighteen randomly selected children aged 7 years from the same school in Jiangmen during December of the same year. The assay of serum 25-OHD concentration used the same technique as that employed in the current study and the assay was performed in the same laboratory. The mean serum 25-OHD for the Jiangmen children was $31 \cdot 1$ (SD 7-4, range 22.6-49.4) $\mathrm{ng} / \mathrm{ml}$ which was not significantly different from the mean value for the twenty Hongkong study children (33.7 (SD 7.7) ng/ml; $P=0 \cdot 170$ ) (W. T. K. Lee, S. S. F. Leung, D. M. Y. Leung, H. S. Y. 
Tsang, J. Lau and J. C. Y. Cheng, unpublished results). These findings suggest that the vitamin D status of children from both Hongkong and Jiangmen was adequate, which may be an important factor for the enhancement of $\mathrm{Ca}$ absorption to occur. Two recent studies of infants from Hongkong and Guangdong, China, showed that serum 25-OHD levels in young Chinese children from both regions were comparable $(20-26 \mathrm{ng} / \mathrm{ml}$; Leung et al. 1989 , 1993). Hongkong and Jiangmen share the same sub-tropical climate and there is plenty of sunshine throughout the year. Study children in this age-group actively engage in outdoor activities; therefore, they should obtain adequate vitamin $D$ through regular exposure to the sun. Thus, the variation in TFCA amongst the study children was unlikely to be related to the difference in vitamin $\mathrm{D}$ nutritional status. Although serum 1,25 dihydroxycholecalciferol level was found to be raised in healthy low-Ca-intake adults (Norman et al. 1981), our findings do not show a significant difference in serum 25-OHD level between the lower- and higher-Ca-intake children $(P=0.66)$ nor was there a correlation between serum 25-OHD concentration and baseline TFCA $(r-0 \cdot 29, P=0 \cdot 21$, $n 20$ ).

Almost all the Jiangmen children in the current study were breast-fed up to 10 months of age. Only one girl was formula-fed from birth to 15 months, and five children were supplemented with formula milk up to about 12 months of age because the mothers could not produce adequate amounts of breast milk. After 1 year of age, five children would occasionally consume a few teaspoons of condensed milk or powdered milk while the rest of the children seldom consumed milk. Thus, the major sources of dietary Ca for Jiangmen children were dark-green vegetables, cereals and bean products. Hence, the habitual $\mathrm{Ca}$ intake of these twelve children from 1 to 7 years was about $300 \mathrm{mg} / \mathrm{d}$ due to the low intake of milk and milk products. All the Hongkong children studied, however, were formula-fed during infancy. Fourteen children (group E) with a current $\mathrm{Ca}$ intake $>500 \mathrm{mg} / \mathrm{d}$ had continued to drink milk since infancy. The remaining eight children (group C) with a current $\mathrm{Ca}$ intake $\leqslant 500 \mathrm{mg} / \mathrm{d}$ gradually reduced the frequency and quantity of milk intake by age 1 year; two of these eight children stopped using milk at age 2 and 4 years respectively, while the remaining six children drank milk occasionally. Thus, the discrepancy in habitual $\mathrm{Ca}$ intake in the study children had already occurred at younger ages. In addition, both Hongkong and Jiangmen are located in soft-water regions. In Hongkong, the mean level of Ca in tap water was $9.9 \mathrm{mg} / \mathrm{ml}$ (The Water Authority of Hongkong, unpublished results); therefore, the contribution of $\mathrm{Ca}$ from drinking water is probably not substantial.

A nutritional adaptive mechanism may operate in children in response to different $\mathrm{Ca}$ exposures. The current study shows that the study children were able to adapt by increasing the rate of $\mathrm{Ca}$ absorption to a moderate extent in response to a low-Ca diet. However, it is interesting to note that even in children on a high $\mathrm{Ca}$ intake, the absorption rate was still as high as $55 \%$. Published values for TFCA and the extent of adaptation to low-Ca diets in Asian and Caucasian children are limited. The findings of the present study agree with earlier balance studies in low-Ca-intake Indian children (Begum \& Pereira, 1969) and Sri Lankan children (Nicholls \& Nimalasuriya, 1939) in that children could adapt to a $\mathrm{Ca}$ intake below $300 \mathrm{mg} / \mathrm{d}$ and were able to maintain positive Ca retention. The mean $\mathrm{Ca}$ retention of twenty-eight rural Indian children (Begum \& Pereira, 1969) subsisting on a diet as low as $200 \mathrm{mg} / \mathrm{d}$ could reach about $60 \%$, and the mean urinary Ca loss was less than $35 \mathrm{mg} / \mathrm{d}$. On the other hand, Nicholls \& Nimalasuriya (1939) showed that Sri Lankan children accustomed to dietary Ca levels of less than $300 \mathrm{mg} / \mathrm{d}$ were able to absorb over $60 \%$ of $\mathrm{Ca}$ from the diet, and the mean total urinary $\mathrm{Ca}$ excretion was $16 \mathrm{mg} / \mathrm{d}$. Matkovic (1991) reviewed ninety-nine metabolic balance studies in children aged 2-8 years; the author observed that the mean urinary $\mathrm{Ca}$ loss dropped from 117 to about $60 \mathrm{mg} / \mathrm{d}$ when 
mean $\mathrm{Ca}$ intakes declined from 1600 to $470 \mathrm{mg} / \mathrm{d}$. These early studies demonstrated that growing children on habitually-low-Ca diets had a low urinary $\mathrm{Ca}$ excretion in addition to a relatively higher $\mathrm{Ca}$ retention so that a positive $\mathrm{Ca}$ balance could be maintained to facilitate skeletal mineralization.

Abrams et al. (1993) employed the dual-tracer technique to compare TFCA of ten healthy Caucasian girls with a mean age of 7.5 (SD 1.4) years; the results were used for comparison with those of children with juvenile rheumatoid arthritis. ${ }^{44} \mathrm{Ca}(0.5 \mathrm{mg} / \mathrm{kg})$ or ${ }^{46} \mathrm{Ca}(0.5 \mu \mathrm{g} / \mathrm{kg})$ was labelled in milk (amount of milk used was not mentioned in the report) and taken orally with a standard breakfast. ${ }^{42} \mathrm{Ca}(0 \cdot 1-0.35 \mathrm{mg} / \mathrm{kg})$ was infused immediately after the breakfast. TFCA of the healthy girls was 30.4 (SD 8.4) \%, and the mean dietary Ca intake of the ten subjects was 940 (SD 470) $\mathrm{mg} / \mathrm{d}$. The higher percentages of TFCA found in the present study when compared with those of Abrams et al. (1993) may be due to adaptive or ethnic differences in the efficiency of $\mathrm{Ca}$ absorption, or slight variations in the study protocols. Miller et al. (1988) and Smith et al. (1987) used a doubleisotope technique to determine TFCA from ${ }^{44} \mathrm{Ca}$-enriched $\mathrm{CaCO}_{3}$ and calcium citratemalate in Caucasian children and adolescents aged 10-17 years. The TFCA from $\mathrm{CaCO}_{3}$ and calcium citrate-malate were 26 and $36 \%$ respectively, which were remarkably lower than those from the present study. In the current study the subjects were younger than those in the studies of Miller et al. (1988) and Smith et al. (1987). In addition, oral ${ }^{44} \mathrm{Ca}$ was administered in chocolate milk as a tracer carrier and the test meal was given to subjects in a fasted state. In contrast, Miller et al. (1988) and Smith et al. (1987) labelled Ca salts with ${ }^{44} \mathrm{Ca}$ (total dose $250 \mathrm{mg} \mathrm{Ca}$ ) and the oral tracer was taken simultaneously with a standard breakfast. Thus, it is inconclusive whether the discrepancy in TFCA between the results of our own study and those of Miller et al. (1988) and Smith et al. (1987) was due to adaptive or ethnic differences or may be attributed to the variations in the study design.

Eastell et al. (1989) used a dual-isotope technique to estimate Ca absorption by labelling dietary $\mathrm{Ca}$ in individual meals rather than in a fixed $\mathrm{Ca}$ carrier. The authors observed a negative correlation between dietary $\mathrm{Ca}$ and the amount of $\mathrm{Ca}$ absorbed. TFCA also varied from meal to meal during the day which may be attributed to the variation in Ca contents of the meals. Thus, in future studies it would be more appropriate to label different meals during the day in order to obtain a more accurate estimate of $\mathrm{Ca}$ absorption based on the entire diet.

The value for fractional $\mathrm{Ca}$ absorption is one of the key factors in estimating $\mathrm{Ca}$ requirements in children (National Research Council, 1989; Department of Health, 1991). In the USA the recommended $\mathrm{Ca}$ intake for children aged between 1 and 10 years was $800 \mathrm{mg} / \mathrm{d}$ based on an assumption that $\mathrm{Ca}$ absorption rate in children is $40 \%$ (National Research Council, 1989). The RDA for Ca for Chinese children based on the mean TFCA extrapolated from the present study may be lower than the US RDA. To investigate any difference in $\mathrm{Ca}$ absorption between Caucasian and Chinese children would necessitate a further absorption study in Caucasian children with the same protocol as that of the present study. Also, it would be worthwhile to assess Ca absorption in Chinese children living in temperate regions of Northern China in order to determine the extent of variations in $\mathrm{Ca}$ absorption which might be influenced by environmental factors such as variations in dietary intakes, vitamin D nutritional status and the frequency of exposure to sunshine.

In conclusion, this is the first $\mathrm{Ca}$ absorption study using the technique of doubly-labelled stable isotopes coupled with TIMS to measure TFCA among Chinese children who had a wide range of $\mathrm{Ca}$ intakes. The results of the study indicate that growing Chinese children accustomed to a habitually-low-Ca diet were able to adapt to enhance the efficiency of $\mathrm{Ca}$ absorption. The vitamin D nutritional status of the study children was within the normal range. The mean TFCA of the Chinese children was above $50 \%$. Further study is necessary 
to determine whether there is any difference in $\mathrm{Ca}$ absorption between Caucasian and Chinese children.

This study was supported in part by the Earmarked Research Grant (\# CUHK 51/91) of the Research Grants Council, Hongkong. The authors are grateful to the study children, parents and teachers from both Hongkong and Jiangmen who were involved in the study. They thank Mr William Tung, Pharmacist, Prince of Wales Hospital, for sterilizing intravenous doses of isotope for injection; $\mathrm{Mr} \mathrm{C}$. S. Ho, Department of Chemical Pathology, Prince of Wales Hospital, for assaying the concentrations of the prepared isotopes; Mr Albert Cheung, Centre for Clinical Trials and Epidemiological Research for helping with statistical analyses; Professor R. Swaminathan, former Professor of Chemical Pathology Department, Professor S. J. Oppenheimer, Department of Paediatrics, The Chinese University of Hongkong, and Dr Ann Prentice of MRC Dunn Nutritional Laboratory, Cambridge, UK for their invaluable advice during the study. The present investigation forms part of the doctoral thesis of W.T.K. L. to be submitted to The Chinese University of Hongkong for partial fulfilment for the PhD degree.

\section{REFERENCES}

Abrams, S. A., Lipnick, R. N., Vieira, N. C., Stuff, J. E. \& Yergey, A. L. (1993). Calcium absorption and metabolism in children with juvenile rheumatoid arthritis assessed using stable isotopes. Journal of Rheumatology 20, 1196-1200.

Anderson, J. J. B. (1992). The role of nutrition in the functioning of skeletal tissue. Nutrition Review 50, $388-394$.

Begum, A. \& Pereira, S. M. (1969). Calcium balance studies on children accustomed to low Ca intakes. British Journal of Nutrition 23, 905-911.

Bingham, S. A. (1987). The dietary assessment of individuals; methods, accuracy, new techniques and recommendations. Nutrition Abstracts and Reviews 57, 705-742.

Burke, B. S. (1947). The dietary history as a tool in research. Journal of the American Dietetic Association 23, $1041-1046$

Chan, E. P. L., Lau, E., Shek, C. C., MacDonald, D., Woo, J., Leung, P. C. \& Swaminathan, R. (1992). Agerelated changes in bone density, serum parathyroid hormone, calcium absorption and other indices of bone metabolism in Chinese women. Clinical Endocrinology 36, 375-381.

Church, C. F. \& Church, H. N. (1975). Food Values of Portions Commonly Used. Philadelphia: J. B. Lippincott Co.

DeGrazia, J. A., Ivanovich, P., Fellows, H. \& Rich, C. (1965). A double label technique for measurement of intestinal absorption of calcium in man. Journal of Laboratory and Clinical Medicine 66, 822-829.

Department of Health (1991). Dietary Reference Values for Food Energy and Nutrients for the United Kingdom. Report on Health and Social Subjects no. 41. London: HM Stationery Office.

Department of Health, Education and Welfare (1972). Food Composition Table for Use in South East Asia. Bethesda, Md: Department of Health, Education and Welfare.

Eastell, R., Vieira, N. E., Yergey, A. L. \& Riggs, L. (1989). One-day test using stable isotopes to measure true fractional calcium absorption. Journal of Bone and Mineral Research 4, 463-468.

Fairweather-Tait, S. J., Johnson, A., Eagles, J., Ganatra, S., Kennedy, H. \& Gurr, M. I. (1989). Studies on calcium absorption from milk using double-label stable isotope technique. British Journal of Nutrition 62 , 379-388.

Food and Agriculture Organization/World Health Organization Expert Group (1962). Calcium Requirements. FAO Nutrition Meetings Report Series no. 230. Rome: FAO.

German Society of Nutrition (1991). Recommendations on Nutrient Intake, 5th revised ed. Frankfurt: German Society of Nutrition.

Grindulis, H., Scott, P. H. \& Belton, N. R. (1986). Combined deficiency of iron and vitamin D in Asian toddlers. Archives of Disease in Childhood 61, 843-848.

Heaney, R. P., Savilie, P. D.\& Recker, R. R. (1975). Calcium absorption as a function of calcium intake. Journal of Laboratory and Clinical Medicine 85, 881-887.

Hegsted, D. M., Moscoso, I. \& Carlos Collazos, C. H. (1952). A study of the minimum calcium requirements of adult. Journal of Nutrition 48, 181-201.

Heumann, K. G. (1988). Isotope dilution mass spectrometry. In Inorganic Mass Spectrometry, pp. $301 \sim 376$ [F. Adams, R. Gijbels and R. van Grieken, editors]. New York: J. Wiley \& Sons.

Hillman, L. S., Tack, E., Covell, D. G., Vieira, N. E. \& Yergey, A. L. (1988). Measurement of true calcium absorption in premature infants using intravenous ${ }^{46} \mathrm{Ca}$ and oral ${ }^{44} \mathrm{Ca}$. Pediatric Research 23, $589-594$.

Ho, Z. C. (1988). Prevalence of nutritional problems in infants and preschool children in China. In Proceedings 
of the Second International Symposium on Maternal and Infant Nutrition, pp. E54-55 [D. L. Yeung and Z. C. Ho, editors]. Guangzhou: Heinz Institute of Nutritional Sciences.

Institute of Health (1980). Food Composition Table. Chinese Academy of Medical Sciences. Beijing: Chinese People's Health Publishing Co.

Jain, M. G. (1989). Diet history: questionnaire and interview techniques used in some retrospective studies of cancer. Journal of the American Dietetic Association 89, 1647-1652.

Lee, W. T. K., Leung, S. S. F., Lui, S. S. H. \& Lau, J. (1993a). Relationship between long-term calcium intake and bone mineral content of children aged from birth to 5 years. British Journal of Nutrition 70, 235-248.

Lee, W. T. K., Leung, S. S. F., Ng, M. Y., Wang, S. F., Xu, Y. C., Zeng, W. P. \& Lau, J. (1993b). Bone mineral content of two populations of Chinese children with different calcium intakes. Bone and Mineral 23, $195-206$.

Leung, S. S. F. \& Lui, S. S. H. (1990). Nutritive value of Hongkong Chinese weaning diet. Nutrition Research 10, $707-715$.

Leung, S. S. F., Lui, S. \& Swaminathan, R. (1989). Vitamin D status of Hongkong Chinese infants. Acta Paediatrica Scandinavica 78, 303-306.

Leung, S. S. F., Wu, M. Y., Yeung, W. M., Wong, C. K. \& Pang, C. P. (1993). Prevalence of nutritional rickets in infants of Quangzhou: accuracy of diagnosing rickets basing on clinical features alone. Hong Kong Journal of Paediatrics 9, 229-232.

Marr, J. W. (1971). Individual dietary surveys: purposes and methods. World Review of Nutrition and Dietetics $13,105-164$.

Matkovic, V. (1991). Calcium metabolism and calcium requirements during skeletal modelling and consolidation of bone mass. American Journal of Clinical Nutrition 54, 245S-260S.

Matkovic, V. (1992). Calcium and peak bone mass. Journal of Internal Medicine 231, 151-160.

Matkovic, V., Fontana, D., Tominac, C., Goel, P. \& Chesnut, C. H. III. (1990). Factors that influence peak bone mass formation: a study of calcium balance and the inheritance of bone mass in adolescent females. American Journal of Clinical Nutrition 52, 878-888.

Miller, J. Z., Smith, D. L., Flora, L., Slemenda, C. \& Jiang, X. (1988). Calcium absorption from calcium carbonate and a new form of calcium (CCM) in healthy male and female adolescents. American Journal of Clinical Nutrition 48, 1291-1294.

Moore, L. J. (1984). Stable isotope measurements with thermal and resonance ionisation mass spectrometry. In Stable Isotopes in Nutrition, pp. 1-26 [J. R. Turnlund and P. E. Johnson, editors]. Washington, DC: American Chemical Society.

Mueller, T. R. \& Walker, R. L. (1987). Isotopic determination of calcium by thermal ionisation using a VG 354 mass spectrometer. Proceedings of the 35th ASMS Conference on Mass Spectrometry and Allied Topics, p. 993. Denver, CO: ASMS.

National Research Council (1989). Food and Nutrition Board: Recommended Dietary Allowances, 10 th ed. Washington, DC: National Academy Press.

Nicholls, L. \& Nimalasuriya, A. (1939). Adaptation to a low calcium intake in reference to the calcium requirements of a tropical population. Journal of Nutrition 18, 563-577.

Nordin, B. E. C. (editor) (1976). Plasma calcium and plasma magnesium homeostasis. In Calcium, Phosphate and Magnesium Metabolism, pp. 186-216. Edinburgh: Churchill Livingstone.

Norman, A. W. (1990). Intestinal calcium absorption: a vitamin D-hormone-mediated adaptive response. American Journal of Clinical Nutrition 51, 290-300.

Norman, D. A., Fordtran, J. S., Brinkley, J., Zerwekh, J. E., Nicar, M. J., Strowig, S. M. \& Pak, C. Y. C. (1981). Jejunal and ileal adaptation to alterations in dietary calcium. Journal of Clinical Investigation 67, $1599-1603$.

Paul, A. A. \& Southgate, D. A. T. (1978). McCance and Widdowson's the Composition of Foods, 4th revised ed. London: HM Stationery Office.

Recker, R. R., Bammi, A., Barger-Lux, M. \& Heaney, R. P. (1988). Calcium absorbability from milk products, an imitation milk, and calcium carbonate. American Journal of Clinical Nutrition 47, 93-95.

Roth, P. \& Werner, E. (1985). Interrelationship of radiocalcium absorption tests and their clinical reference. Mineral and Electrolyte Metabolism 11, 351-357.

Smith, K. T., Heaney, R. P., Flora, L. \& Hinders, S. M. (1987). Calcium absorption from calcium citrate-malate. Calcified Tissues International 41, 351-352.

Tackett, J. R. \& Ellefson, R. E. (1987). Isotopic analysis of calcium. Proceedings of the 35th ASMS Conference on Mass Spectrometry and Allied Topics, Abstr. Denver, CO: ASMS.

Tung, T. C., Huang, P. C. \& Li, H. C. (1961). Composition of foods used in Taiwan. Journal of the Formosan Medical Association 60, 973-1005.

Watt, B. K. \& Merrill, H. L. (1983). Composition of Foods, Agriculture Handbook no. 8. Washington, DC: Department of Agriculture.

Woo, J., Swaminathan, R., Pang, C. P., Mak, Y. T. \& MacDonald, D. (1990). A comparison of biochemical indices of bone turnover in elderly institutionalised and free-living subjects. Bone and Mineral 8, 31-38.

Yergey, A. L., Vieira, N. E. \& Covell, D. G. (1987). Direct measurement of dietary functional absorption using calcium isotopic tracers. Biochemical and Environmental Mass Spectrometry 14, 603-607. 